\title{
SKRINNING FITOKIMIA, UJI AKTIVITAS ANTIOKSIDAN DAN TABIR SURYA PADA TANAMAN JAGUNG (Zea mays L.)
}

\author{
David Albert Pangemanan', Edi Suryanto' ${ }^{1)}$, Paulina V. Y. Yamlean ${ }^{1)}$ \\ ${ }^{1)}$ Program Studi Farmasi FMIPA UNSRAT Manado, 95115
}

\begin{abstract}
Corn (Zea Mays L.) is widely developed in Indonesia. Corn kernels showed total phenolic and antioxidant activity. Antioxidants have the potential as photoprotectors, therefore, plants containing phenolic compounds can be used in the prevention of free radicals. For this reason, researcher is interested in further researching the phytochemical screening, antioxidant activity and sunscreen testing from extracts of stems, leaves, hair and leaf wrapping from corn (Zea mays L.). The samples used were corn plants (corn silk, corn leaves, corn stalks and leaf wrapping corn) originating from Kauditan area, North Minahasa. The results of the study showed that the leaf contained saponin and flavonoid compounds, the stem contained alkaloid and saponin compounds, the hair contained alkaloid and flavonoid compounds, and the leaf wrapping only contained alkaloid compounds. The highest to lowest total phenolic content values starting from the stem were $46.93 \mu \mathrm{g} / \mathrm{mL}$, the leaf wrapping $37.76 \mu \mathrm{g} / \mathrm{mL}$, the leaf $26.63 \mu \mathrm{g} / \mathrm{mL}$ and hair $14.49 \mu \mathrm{g} / \mathrm{mL}$. The leaf has the highest antioxidant activity with a value of $72.81 \%$ followed by $62.87 \%$ stem then wrapping leaf $43.13 \%$ and finally hair $29.14 \%$. The SPF value of the stem was included in the ultra protection with a value of 16.117 followed by the leaves included in the maximum protection with an SPF value of 10.902. While the hair with SPF value of 0.6 and wrapping leaf with SPF value of 0.222 are included in the minimum protection.
\end{abstract}

Keywords: Corn (Zea Mays L.), Sunscreen, Antioxidants, Phenol

\begin{abstract}
ABSTRAK
Jagung (Zea Mays L.) banyak dikembangkan di Indonesia. Biji jagung menunjukkan kadar total fenolik dan aktivitas antioksidan. Antioksidan memiliki potensi sebagai fotoprotektor, oleh karena itu, tanaman yang mengandung senyawa fenolik dapat digunakan dalam pencegahan radikal bebas. Untuk itu peneliti tertarik untuk meneliti lebih lanjut tentang skrining fitokimia, uji aktivitas antioksidan dan tabir surya dari ekstrak batang, daun, rambut, dan daun pembungkus dari jagung (Zea mays L.). Sampel yang digunakan ialah tanaman jagung (rambut jagung, daun jagung, batang jagung dan daun pembungkus jagung) yang berasal dari daerah Kauditan, Minahasa Utara. Hasil dari penelitian menunjukkan daun mengandung senyawa saponin dan flavonoid, batang mengandung senyawa alkaloid dan saponin, rambut mengandung senyawa alkaloid dan flavonoid, dan daun pembungkus hanya mengandung senyawa alkaloid. Nilai kandungan total fenolik yang paling tinggi sampai paling rendah dimulai dari batang sebesar $46.93 \mu \mathrm{g} / \mathrm{mL}$, daun pembungkus $37.76 \mu \mathrm{g} / \mathrm{mL}$, daun $26.63 \mu \mathrm{g} / \mathrm{mL}$ dan rambut $14.49 \mu \mathrm{g} / \mathrm{mL}$. Daun memiliki aktivitas antioksidan yang paling tinggi dengan nilai $72.81 \%$ diikuti oleh batang $62.87 \%$ kemudian daun pembungkus $43.13 \%$ dan yang terakhir adalah rambut $29.14 \%$. Nilai SPF batang termasuk dalam proteksi ultra dengan nilai 16,117 diikuti oleh daun yang termasuk dalam proteksi maksimal dengan nilai SPF 10,902. Sedangkan rambut dengan nilai SPF 0,6 dan daun pembungkus dengan nilai SPF 0,222 termasuk dalam proteksi minimal.
\end{abstract}

Kata Kunci : Jagung (Zea Mays L.), Tabir Surya, Antioksidan, Fenol 


\section{PENDAHULUAN}

Jagung (Zea Mays L.) dikenal dengan nama sweetcorn banyak dikembangkan di Indonesia. Jagung banyak dikonsumsi karena memiliki rasa yang lebih manis, aroma lebih harum, dan mengandung gula sukrosa serta rendah lemak sehingga baik dikonsumsi bagi penderita diabetes (Putri, 2011). Sebagai salah satu tanaman pangan paling penting, jagung berkembang secara luas (Liu et al, 2016). Umur produksi jagung manis lebih singkat (genjah), sehingga dapat menguntungkan dari sisi waktu (Palungkun dan Asiani, 2004).

Sulawesi Utara memiliki varietas jagung lokal yang unggul salah satunya yaitu jagung Manado kuning. Jenis jagung Manado kuning masih kurang digunakan sebagai bahan pangan yang biasa dikonsumsi oleh masyarakat karena memiliki tekstur yang keras, dan biasanya di jadikan sebagai pakan untuk hewan ternak. Menurut Demak (2017), pemanggangan biji jagung Manado kuning pada $160^{\circ} \mathrm{C}$ menunjukkan total fenolik dan aktivitas antioksidan yang paling tinggi. Jagung Manado kuning memiliki kandungan fitokimia fenolik dan karotenoid serta aktivitas antioksidan (Landeng et al., 2017; Budiarso et al., 2017). Tanaman jagung kuning memiliki kualitas lebih baik dibandingkan jagung putih, karena warna kuning diakui sebagai sumber provitamin A (Hwang et al., 2016; Shahidi, 1997).

Menurut Suryanto (2012), tubuh manusia secara terus menerus mengalami proses oksidasi yang menghasilkan oksigen aktif dan radikal bebas. Reaksi radikal bebas dengan molekul lain dapat berlangsung secara berkesinambungan dan menimbulkan reaksi berantai, dan jika hal tersebut berlangsung secara terus menerus akan menimbulkan berbagai macam gangguan kesehatan seperti kanker, jantung, penuaan dini serta penyakit degenerative lainnya (Antolovich et al., 2002).
Black (1990) menyatakan bahwa antioksidan memiliki potensi sebagai fotoprotektor, oleh karena itu, tanaman yang mengandung senyawa fenolik dapat digunakan dalam pencegahan generasi radikal bebas oksigen dan peroksidasi lipida yang diinduksi oleh cahaya UV. Nilai SPF yang didapat untuk konsentrasi $2,5 \%$ dan $5 \%$ ialah 3,$2 ; 3,8$ sudah memiliki kemampuan tabir surya dalam proteksi minimal. Untuk konsentrasi $7,5 \%$ nilainya berada diantara proteksi minimal dan proteksi sedang 4,4 (Wenur, 2016).

Sinar ultraviolet (UV) adalah bagian dari sinar matahari yang merupakan suatu gelombang elektromagnetik. Adanya paparan radiasi sinar UV dapat membahayakan kulit karena dapat menyebabkan eritema, pigmentasi, fotosensitivitas, penuaan dini hingga kanker kulit (Satiadarma dan Suyoto, 1986; Saewan and Jimtaisong, 2013). Salah satu upaya untuk melindungi kulit adalah menggunakan tabir surya (sunscreen). Efektivitas tabir surya biasa dinyatakan dengan SPF (Sun Protection Factor) yang merupakan perbandingan ukuran berapa banyak UV yang diperlukan untuk membakar kulit ketika dilindungi dan tidak dilindungi oleh tabir surya (Laeliocattleya et al., 2014).

Paparan sinar matahari adalah sumber pembentuk senyawa radikal bebas. Radikal bebas merupakan molekul yang memiliki satu atau lebih elektron yang tidak berpasangan. Elektron-elektron yang tidak berpasangan ini menyebabkan radikal bebas menjadi senyawa yang sangat reaktif terhadap sel-sel tubuh dengan cara mengikat elektron molekul sel (Pietta, 1999; Wijaya, 1996). Rekasi ini sering disebut sebagai oksidasi, berbagai bukti ilmiah menunjukkan bahwa resiko penyakit kronis akibat senyawa radikal bebas dapat dikurangi dengan memanfaatkan peran senyawa antioksidan seperti vitamin C, E, A, karoten, asam-asam fenol, polifenol dan 
flavonoid (Prakash, 2001; Okawa et al., 2001). Menurut Adom dan Liu (2002) jagung menunjukkan potensi aktivitas antioksidan.

Penelitian yang telah dilakukan oleh Solihah et al., (2012), rambut jagung mengandung senyawa fenol, flavonoid, tannin dan alkaloid. Penelitian Lumempow et al., 2012) untuk tongkol jagung telah terbukti mengandung senyawa fenolik yang sejalan dengan nilai SPF. Dari uraian diatas dan kandungan fitokimia yang terdapat pada rambut dan tongkol jagung maka peneliti tertarik untuk meneliti lebih lanjut tentang skrining fitokimia, uji aktivitas antioksida dan tabir surya dari ekstrak batang, daun, rambut, dan daun pembungkus dari jagung (Zea mays L.).

\section{METODOLOGI PENELITIAN}

\section{Waktu dan Tempat Penelitian}

Penelitian ini akan dilaksanakan pada bulan Oktober 2018 - Oktober 2019 di Laboratorium Unit Pelayanan Terpadu, Universitas Sam Ratulangi Manado.

\section{Alat dan Bahan}

\section{Alat}

Peralatan yang digunakan dalam penelitian yaitu alat-alat gelas tabung reaksi, erlenmeyer, gelas kimia, gelas Arloji, gelas ukur (Pyrex Iwaki dan Schott Duran) labu bulat, rak tabung, mikropipet, mikro buret, aluminium foil, botol serum, ayakan 60 mesh, vortex, cawan porselin, spatula stainless steel, neraca analitik ER-180 A, rotary evaporator, Spektrofotometer UV-Vis

\section{Bahan}

Bahan yang digunakan terdiri dari Tanaman Jagung, akuades, Etanol 80\%, Etanol 95\%, Etanol p.a, larutan DPPH, Reagen uji fitokimia (Liebearmann-burchard, Pereaksi dragendorff, Pereaksi meyer, $\mathrm{HCl}$ pekat, $\mathrm{NaOH}$, Serbuk magnesium, larutan natrium karbonat $2 \%$, reagen Folin-Ciocalteu $50 \%)$.

\section{Prosedur Penelitian \\ Pengambilan Sampel}

Bahan yang digunakan ialah tanaman jagung (rambut jagung, daun jagung, batang jagung dan daun pembungkus jagung) yang berumur \pm 90 hari berasal dari daerah Kauditan, Minahasa Utara.

\section{Ekstraksi}

Ditimbang sampel sebanyak $50 \mathrm{~g}$ dan diekstraksi menggunakan metode maserasi dengan pelarut Etanol 80\% sebanyak $500 \mathrm{~mL}$ selama 1x24 jam kemudian disaring dengan menggunakan kertas saring dan diperoleh filtrat serta endapan. Dilakukan 2x penggulangan. Filtrat dipekatkan menggunakan rotary evaporator.

\section{Skrining Fitokimia}

Ektrak kental masing - masing bagian tanaman dianalisis fitokimia yang meliputi uji alkaloid, triterpenoid dan steroid, saponin, dan flavonoid. Metode skrining yang digunakan berdasarkan pada Harborne (1987).

a. Alkaloid

Sebanyak $0.1 \mathrm{~g}$ ekstrak kental ditambahkan dengan $2 \mathrm{~mL}$ pereaksi alkaloid yaitu pereaksi dragendorff dan pereaksi meyer kemudian di vortex. Hasil uji positif diperoleh bila terbentuk endapan merah dengan pereaksi dragendorff dan endapan putih kekuningan dengan pereaksi meyer.

b. Triterpenoid dan steroid

Sebanyak $0.1 \quad \mathrm{~g}$ ekstrak ditambahkan dengan $1 \mathrm{~mL}$ pereaksi Libearmann Burchard kemudian dikocok. Reaksi positif ditunjukkan dengan terbentuknya larutan berwarna 
biru hijau untuk pertama kali kemudian berubah menjadi berwarna merah.

c. Saponin (uji busa)

Sebanyak $0.05 \mathrm{~g}$ ekstrak ditambahkan etanol $3 \mathrm{~mL}$ kemudian dipanaskan sampai mendidih. Larutan lalu didinginkan dan ditambahkan aquades sebanyak $3 \mathrm{~mL}$. Jika terdapat busa setinggi $1 \mathrm{~cm}$ dan bertahan selama 10 menit setelah larutan dikocok berarti sampel positif mengandung saponin.

d. Flavonoid

Sebanyak $0.05 \mathrm{~g}$ ekstrak ditambahkan ditambahkan dengan 2.5 $\mathrm{mL}$ etanol $95 \%$ kemudian dipanaskan sampai mendidih lalu didinginkan. Diambil $1 \mathrm{~mL}$ dari larutan dan ditambahkan 2 tetes HCL pekat dan $0.1 \mathrm{mg}$ bubuk $\mathrm{Mg}$. Selanjutnya dikocok dan didiamlan selama 3 menit. Reaksi positif ditunjukkan dengan terbentuknya warna merah kekuningan.

e. Tannin

Sebanyak $0.05 \mathrm{~g}$ ekstrak ditambahkan Etanol 95\% kemudian dikocok lalu didiamkan selama 3 menit. Diambil $1 \mathrm{~mL}$ dari larutan kemudian ditambahkan 3 tetes $\mathrm{FeCl} 3$ $1 \%$, selanjutnya dikocok dan diamati. Reaksi positif ditunjukkan dengan terbentuknya warna hitam kehijauan.

\section{Penentuan Kandungan Total Fenolik}

Kandungan total fenolik ekstrak masing-masing bagian tanaman jagung ditentukan menggunakan metode Folin Ciocalteu (Conde et al., 1997). Sebanyak 0,1 $\mathrm{mL}$ larutan ekstrak konsentrasi $1000 \mu \mathrm{g} / \mathrm{mL}$ dimasukkan ke dalam tabung reaksi, lalu ditambahkan 0,1 mL reagen Folin Ciocalteu $50 \%$. Campuran tersebut divortex, lalu ditambahkan $2 \mathrm{~mL}$ larutan $\mathrm{Na}_{2} \mathrm{CO}_{3} \quad 2 \%$. Selanjutnya campuran diinkubasi dalam ruang gelap selama 30 menit. Absorbansinya dibaca pada $\lambda 750 \mathrm{~nm}$ spektrofotometer UV-Vis.

\section{Penentuan Aktivitas Antioksidan dengan DPPH}

Penentuan aktivitas penangkal radikal bebas menurut Burda dan Oleszeck (2001). Sebanyak 0,5 mL masing-masing ekstrak ditambahkan dengan 1,5 mL larutan ekstrak $1000 \mu \mathrm{g} / \mathrm{mL}, \quad$ 1,1-difenil-2-pikrilhidrazil (DPPH) dalam etanol dan divorteks selama 2 menit. Berubahnya warna larutan dari ungu ke kuning menunjukkan efisiensi penangkal radikal bebas. Inkubasi selama 30 menit dan absorbansi diukur pada $\lambda 517 \mathrm{~nm}$ dengan menggunakan spektrofotometer UV-Vis. $\alpha$ tokoferol (VE) dengan konsentrasi $50 \mu \mathrm{g} / \mathrm{mL}$ digunakan sebagai sampel pembanding. Aktivitas penangkal radikal bebas dihitung sebagai presentase berkurangnya warna DPPH dengan menggunakan persamaan:

Aktivitas penangkal radikal bebas $(\%)=$

$$
\left(1-\frac{\text { absorbansi sampel }}{\text { absorbansi kontrol }}\right) \times 100 \%
$$

\section{Penentuan Nilai SPF Secara in-vitro}

Penentuan efektifitas tabir surya dilakukan dengan menentukan nilai SPF secara In Vitro dengan menggunakan spektrofotometer. Ekstrak masing-masing bagian tanaman jagung diencerkan menjadi $1000 \mu \mathrm{g} / \mathrm{mL}$ kemudian dibaca pada spektrofotometer.

Dibuat kurva serapan uji dalam kuvet, dengan panjang gelombang antara 290-360 $\mathrm{nm}$, gunakan etanol sebagai blangko $50 \%$. Kemudian tetapkan serapan rata-ratanya (Ar) dengan interval $5 \mathrm{~nm}$. Kemudian dihitung dengan rumus : 
$\mathrm{SPF}=\mathrm{CF} \times \sum_{290}^{320} E E(\lambda) \times \mathrm{I}(\lambda) \mathrm{x}$ absorbansi ( $\lambda) \ldots \ldots \ldots \quad$ (Pers.2)

Keterangan :

CF : Faktor Koreksi (10)

EE : Efisiensi eriternal

I : Spektrum simulasi sinar surya

\section{HASIL DAN PEMBAHASAN}

\section{Ekstraksi}

Sampel yang digunakan dalam penelitian ini adalah daun, daun pembungkus, batang dan rambut dari jagung Manado kuning yang dibuat menjadi serbuk. Serbuk diperoleh dengan menghaluskan sampel dengan menggunakan blender, yang bertujuan untuk memperkecil ukuran sampel. Semakin kecil ukuran sampel, semakin besar luas permukaan sehingga dapat mempengaruhi interaksi sampel dengan pelarut maka proses ekstraksi secara maserasi berlangsung optimal dan menghasilkan ekstrak yang maksimal. Penelitian ini menggunakan proses ekstraksi maserasi. Sampel daun, daun pembungkus, batang dan rambut jagung Manado kuning masing-masing sebanyak $50 \mathrm{~g}$ diekstraksi dengan pelarut Etanol $80 \%$.

Tabel 1. Rendemen ekstrak dari masing masing bagian tanaman jagung Manado kuning

\begin{tabular}{ccc}
\hline Sampel & Massa (g) & $\begin{array}{c}\text { Rendemen } \\
(\%)\end{array}$ \\
\hline $\begin{array}{c}\text { Ekstrak } \\
\text { daun }\end{array}$ & 4.42 & 8.84 \\
$\begin{array}{c}\text { Ekstrak d. } \\
\text { pembungkus } \\
\text { Ekstrak } \\
\text { batang }\end{array}$ & 1.53 & 3.06 \\
$\begin{array}{c}\text { Ekstrak } \\
\text { rambut }\end{array}$ & 1.39 & 8.93 \\
\hline
\end{tabular}

Maserasi adalah proses perendaman sampel untuk menarik komponen yang diinginkan pada jangka waktu tertentu. Keuntungannya yakni, lebih praktis, pelarut yang digunakan lebih sedikit, dan tidak memerlukan pemanasan, tetapi waktu yang dibutuhkan relatif lama (Putri et al., 2011).

Ekstraksi maserasi dipilih karena merupakan metode yang sederhana dan mudah dilakukan. Pada proses maserasi, sampel mengalami pemecahan dinding sel dan membran sel akibat perbedaan tekanan antara di dalam dan di luar sel sehingga metabolit sekunder yang ada dalam sitoplasma akan terlarut dalam pelarut atau terjadi proses difusi. Penggunaan pelarut etanol pada proses maserasi, bertujuan untuk mengekstrak senyawa metabolit sekunder yang terkandung dalam tumbuhan. Menurut Harborne (1987), pelarut etanol diduga mempunyai sifat yang dapat melarutkan semua jenis komponen yang berupa senyawa polar, non polar dan semi polar.

\section{Skrining Fitokimia}

Hasil skrining fitokimia dari masingmasing bagian tanaman jagung Manado kuning dapat dilihat pada tabel 2.

Tabel 2. Hasil skrining fitokimia dari ekstrak masing - masing bagian tanaman jagung Manado kuning.

\begin{tabular}{|c|c|c|c|c|c|}
\hline \multirow[b]{2}{*}{ Sampel } & \multicolumn{4}{|c|}{ Uji } & \multirow[b]{2}{*}{$\begin{array}{l}\mathrm{Ta} \\
\operatorname{nin}\end{array}$} \\
\hline & $\begin{array}{c}\text { Alkaloi } \\
\mathrm{d}\end{array}$ & $\begin{array}{c}\text { Saponi } \\
\mathrm{n}\end{array}$ & $\begin{array}{l}\text { Stero } \\
\text { id }\end{array}$ & $\begin{array}{c}\text { Flavon } \\
\text { oid }\end{array}$ & \\
\hline $\begin{array}{c}\text { Ekstrak } \\
\text { daun }\end{array}$ & - & + & - & + & - \\
\hline $\begin{array}{l}\text { Ekstrak d. } \\
\text { pembungku } \\
\text { s }\end{array}$ & + & - & - & - & - \\
\hline $\begin{array}{c}\text { Ekstrak } \\
\text { batang }\end{array}$ & + & + & - & - & - \\
\hline $\begin{array}{l}\text { Ekstrak } \\
\text { rambut }\end{array}$ & + & - & - & + & - \\
\hline
\end{tabular}

Ket. Tanda (+) positif mengandung senyawa dan tanda $(-)$ negatif mengandung senyawa 
Dari hasil yang tertera pada tabel dapat dilihat bahwa ekstrak daun mengandung senyawa saponin dan flavonoid, ekstrak batang mengandung senyawa alkaloid dan saponin, ekstrak rambut mengandung senyawa alkaloid dan flavonoid, dan ekstrak daun pembungkus hanya mengandung senyawa alkaloid.

\section{Kandungan Total Fenolik}

Hasil ekstraksi dari masing-masing bagian tanaman jagung (daun, daun pembungkus, batang dan rambut) diencerkan dengan etanol p.a. menjadi konsentrasi 1000 $\mu \mathrm{g} / \mathrm{mL}$. Kemudian diuji kandungan total fenolik dengan reagen Folin-Ciocalteau. Penambahan $\mathrm{Na}_{2} \mathrm{CO}_{3} 2 \%$ dimaksudkan agar suasana larutan menjadi basa karena reaksi ini tidak terjadi dalam suasana asam (Nely, 2007). Metode ini didasarkan pada kemampuan ekstrak untuk mereduksi reagen Folin-Ciocalteu (Julkunen-Tiito, 1985).

Warna biru yang terdapat pada larutan hasil uji menunjukkan adanya kandungan fenolik pada sampel. Dapat dilihat pada lampiran, adanya warna biru pekat pada ekstrak batang dan daun pembungkus sedangkan pada ekstrak daun dan rambut ada warna biru tetapi tidak terlalu terlihat. Menurut Singleton dan Rossi (1965), warna biru yang teramati berbanding lurus dengan konsentrasi ion fenolat yang terbentuk, semakin besar konsentrasi senyawa fenolik maka semakin banyak ion fenolat yang terbentuk sehingga warna biru yang dihasilkan semakin pekat.
Tabel 3. Kandungan total fenolik dari masingmasing bagian tanaman jagung Manado kuning

\begin{tabular}{cc}
\hline Sampel & $\begin{array}{c}\text { Total fenolik } \\
(\mu \mathrm{g} / \mathrm{mL})\end{array}$ \\
\hline Ekstrak daun & $26.63 \pm 0.01^{\mathrm{b}}$ \\
Ekstrak d. pembungkus & $37.76 \pm 0.02^{\mathrm{bc}}$ \\
Ekstrak batang & $46.93 \pm 0.02^{\mathrm{c}}$ \\
Ekstrak rambut & $14.49 \pm 0.01^{\mathrm{a}}$ \\
\hline
\end{tabular}

Berdasarkan Tabel 3 dapat diketahui bahwa nilai kandungan total fenolik yang paling tinggi sampai paling rendah secara berturut-turut dimulai dari ekstrak batang sebesar $46.93 \mu \mathrm{g} / \mathrm{mL}$, ekstrak daun pembungkus $37.76 \mu \mathrm{g} / \mathrm{mL}$, ekstrak daun $26.63 \mu \mathrm{g} / \mathrm{mL}$ dan ekstrak rambut 14.49 $\mu \mathrm{g} / \mathrm{mL}$.

Kandungan fenolik dengan metode Folin-Ciocalteau ditunjukkan dengan berubahnya warna larutan dari kuning menjadi biru, di karenakan reagen FolinCiocalteau yang mengandung senyawa asam fosfomolibdat - fosfotungstat yang direduksi oleh sampel sehingga membentuk senyawa kompleks molibdenum tungstat berwarna biru. Warna biru yang terbentuk akan semakin pekat setara dengan konsentrasi ion fenolat yang terbentuk, artinya semakin besar konsentrasi senyawa fenolik maka semakin banyak ion yang mereduksi asam heteropoli sehingga warna biru yang dihasilkan semakin pekat. Semakin besar intensitas warna yang ditunjukkan maka akan semakin besar kandungan fenol yang terkandung (JulkenenTitto, 1985). 
Penentuan kandungan total fenolik masing-masing ekstrak dinyatakan sebagai ekuivalen asam galat atau Gallic Acid Equivalent (GAE). Ekuivalen asam galat merupakan acuan umum untuk mengukur sejumlah senyawa fenolik yang terdapat dalam suatu bahan (Mongkolsilp et al., 2004). Penggunaan asam galat sebagai larutan standar dikarenakan senyawa asam galat mempunyai gugus hidroksil dan ikatan rangkap yang terkonjugasi pada masingmasing cincin benzena yang menyebabkan senyawa ini sangat efektif untuk membentuk senyawa kompleks dengan reagen FolinCiocalteu, sehingga reaksi yang terjadi lebih sensitif dan intensif. (Julkunen-Tiito, 1985)

Hasil analisis Duncan menunjukkan bahwa ekstrak batang memiliki kandungan total fenolik yang sama dengan ekstrak daun pembungkus dan mempunyai perbedaan yang nyata terhadap ekstrak rambut dan ekstrak daun.

\section{Aktivitas Antioksidan dengan DPPH}

Metode yang digunakan dalam pengujian aktivitas antioksidan adalah metode serapan radikal DPPH (1,1-difenil-2pikrilhidrazil) karena merupakan metode yang sederhana, cepat, mudah, dan menggunakan sampel dalam jumlah yang sedikit dengan waktu yang singkat (Hanani, 2005). Selain itu metode ini terbukti akurat dan praktis (Pratimasari, 2009). Senyawa DPPH merupakan sebuah molekul yang mengandung senyawa radikal bebas nitrogen yang tidak stabil yang dapat mengikat ion hidrogen sehingga digunakan untuk pengujian aktivitas antioksidan. Adanya senyawa antioksidan dari sampel mengakibatkan perubahan warna pada larutan DPPH dalam etanol yang semula berwarna ungu pekat menjadi kuning pucat (Permana et al, 2003). Ketika larutan DPPH dicampur dengan suatu senyawa yang dapat mendonasikan atom hidrogen, maka DPPH berubah menjadi bentuk tereduksi (1,1-difenil-2-pikrihidrazin) dengan kehilangan warna ungu menjadi warna kuning. Perubahan warna kuning ini menghasilkan senyawa bukan radikal (1,1difenil-2-pikrihidrazin) dan radikal (A) (Suryanto, 2012). Metode penangkalan radikal ini melalui mekanisme pengambilan atom hidrogen dari senyawa antioksidan oleh radikal bebas sehingga radikal bebas ini menangkap satu elektron dari senyawa antioksidan (Pokorny et al., 2001). Gambar 1 menunjukkan aktivitas antioksidan dari ekstrak masing-masing bagian tanaman jagung Manado kuning yang diuji menggunakan radikal bebas DPPH.

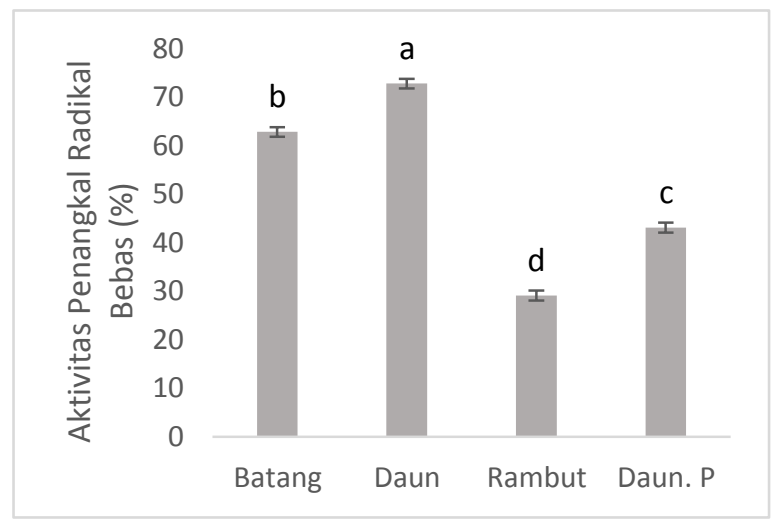

Gambar 1. Aktivitas antioksidan dari masingmasing bagian tanaman jagung

Hasil analisis penangkal radikal bebas pada masing-masing bagian tanaman jagung menunjukkan bahwa ekstrak daun memiliki aktivitas antioksidan yang paling tinggi dengan nilai $72.81 \%$ diikuti oleh ekstrak batang $62.87 \%$ kemudian ekstrak daun pembungkus $43.13 \%$ dan yang terakhir adalah ekstrak rambut 29.14\%. Dapat dilihat bahwa hasil analisis tidak berbanding lurus dengan kandungan total fenolik dari masing-masing bagian tanaman jagung. 
Pada kandungan total fenolik terlihat batang memiliki kandungan fenolik paling tinggi akan tetapi ekstrak daun yang memiliki aktivitas antioksidan tertinggi. Hal ini menunjukkan bahwa aktivitas antioksidan tidak selalu bergantung pada kadar total fenolik, jenis komponen kimia pun dapat mempengaruhi besar aktivitas antioksidan suatu senyawa (Martono et al., 2010).

Komponen utama yang terekstraksi pada daun adalah senyawa fenolik bebas yang komponen utamanya merupakan aglikon (flavonoid yang tidak terikat dengan gula) yang memiliki aktivitas antioksidan lebih tinggi dibandingkan komponen glikon (flavonoid yang terikat dengan gula) (Huang et al.,1992), sehingga aktivitas antioksidan ekstrak daun lebih tinggi dibanding ekstrak lainnya. Seusai dengan Parra et al. (2007), yang menunjukkan bahwa senyawa fenolik terikat lebih tinggi nilainya dibandingkan dengan fenolik bebas. Aktivitas antioksidan pada senyawa fenolik terikat lebih rendah karena senyawa fenolik terikat merupakan flavonoid yang terikat dengan gula yang kekurangan 3 hidroksil bebas pada cincin $\mathrm{C}$ (karbon) sehingga kemampuan untuk mendonorkan atom hidrogennya berkurang (Huang et al.,1992).

Berdasarkan hasil analisis Duncan menunjukkan bahwa ekstrak daun memiliki perbedaan yang nyata terhadap ekstrak batang, ekstrak daun pembungkus dan ekstrak rambut.

\section{Nilai SPF dengan In vitro}

\section{Analisis secara in vitro, dilakukan dengan menggunakan metode spektrofotometri UV-Vis dengan cara menghitung nilai absorbansi sampel yang dibaca pada panjang gelombang 290-400 nm kemudian setiap interval $5 \mathrm{~nm}(290-320 \mathrm{~nm})$. Metode ini untuk mengindikasikan kemampuan sebagai fotoproteksi terhadap}

sinar matahari khususnya UV-B (290-320). Menurut Wasitaadmatja (1997), pembagian tingkat kemampuan tabir surya sebagai berikut: minimal bila SPF antara 2-4; sedang bila SPF antara 4-6; ekstra bila SPF antara 68; maksimal bila SPF antara 8-15; ultra bila SPF lebih dari 15.

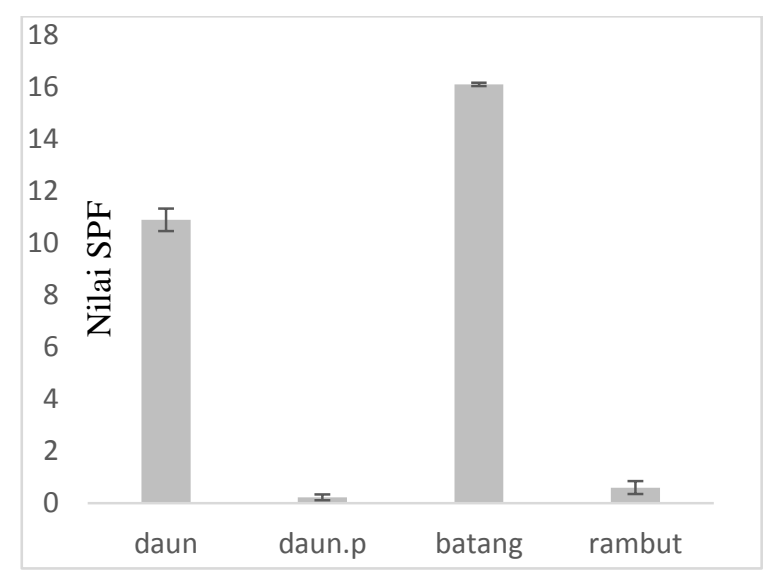

Gambar 2. Nilai SPF dari masing-masing bagian tanaman jagung

Dapat dilihat dari Gambar 2 bahwa ekstrak batang termasuk dalam proteksi ultra dengan nilai SPF yaitu 16,117 diikuti oleh daun yang termasuk dalam proteksi maksimal dengan nilai SPF yaitu 10,902. Sedangkan ektrak rambut dengan nilai SPF 0,6 dan ekstrak daun pembungkus dengan nilai SPF 0,222 termasuk dalam proteksi minimal.

Hasil yang didapat menunjukkan bahwa semakin tinggi kandungan senyawa fenolik semakin meningkat kemampuan sebagai tabir surya yang terbukti mampu melindungi kulit dari kerusakan akibat efek induksi dari radiasi UV. Fenol merupakan senyawa aromatik yang dapat memberikan serapan didaerah spektrum UV karena adanya ikatan rangkap tunggal terkonjugasi sehingga dapat berkhasiat sebagai tabir surya. Menurut Lumempouw et al., (2012), senyawa yang berfungsi sebagai antioksidan yaitu fenolik yang juga sejalan dengan nilai Sun Protection Factor. Senyawa dalam tabir surya mampu 
melindungi kulit karena adanya ikatan yang dapat saling berkonjugasi sehingga ikatan tersebut akan beresonansi saat terpapar sinar UV sehingga akan menurunkan energi dan bersifat melindungi kulit (Prasiddah et al., 2016).

Berdasarkan hasil analisis Duncan terdapat perbedaan nyata pada masing-masing ekstrak. Hasil analisis menunjukkan bahwa ekstrak batang memiliki nilai SPF yang paling tinggi diikuti oleh ekstrak daun pembungkus kemudian ekstrak daun dan ekstrak rambut.

\section{KESIMPULAN}

Berdasarkan dari hasil penelitian yang didapat, maka dapat disimpulkan bahwa :

a. Hasil skrining fitokimia tanaman jagung (Zea mays L.) ekstrak daun mengandung senyawa saponin dan flavonoid; ekstrak daun pembungkus hanya mengandung senyawa alkaloid; ekstrak batang mengandung senyawa alkaloid dan saponin; sedangkan ekstrak rambut mengandung senyawa alkaloid dan flavonoid.

b. Aktivitas antioksidan dari tanaman jagung yang paling tinggi terdapat pada ekstrak daun kemudian ekstrak batang, ekstrak daun pembungkus dan ekstrak rambut.

c. Nilai SPF pada tanaman jagung sesuai dengan kandungan total fenolik. Ekstrak batang memiliki nilai SPF tertinggi diikuti oleh ekstrak daun pembungkus kemudian ekstrak daun dan ekstrak rambut.

\section{SARAN}

Perlu dilakukan penelitian lebih lanjut untuk menjelaskan kandungan senyawa aktif pada tanaman jagung (Zea mays L.) serta uji aktivitasnya.

\section{DAFTAR PUSTAKA}

Antolovich, M., Prenzeler, P. D., Patsalides, E., McDonald, S. dan Robards, K. 2002. Methods for Testing Antioxidant Activity. Analyst. 127(183-198).

Black. H. S. 1990. Antioxidants and Carotenoids as Potential Photoprotectans. Sunscreen Development Evaluation and Regulatory Prospects. Marcel Dekker Inc., New York.

Budiarso, F. S., Suryanto, E. dan Yudishtira, A. 2017. Ekstraksi dan Aktivitas Antioksidan dari Biji Jagung Manado Kuning (Zea mays L.). Pharmacon. 6(3).

Conde, E. E., Cadahia, M. C., Garcia-Vallejo, B. F. D., Simon dan Adrados, J. R. G. 1997. Low Molecular Weight Polyphenol in Cork of Querceus Suber. Journal Agriculture Food Chemical. 45.

Demak, K. U., Putri., Suryanto, E. dan Pontoh, J. 2017. Efek Pemanggangan Terhadap Aktivitas Antioksidan dan Kandungan Fenolik dari Jagung Manado Kuning. Chemistry Progress. 10: $20-25$.

Hanani, E. A., Mun'im, R. dan Sekarini. 2005. Identifikasi Senyawa Antioksidan Dalam Spons Callyspongia SP Dari Kepulauan Seribu. Majalah Ilmu Kefarmasian. 2(127-133).

Harborne, J. B. 1987. Metode Fitokimia : penuntun Cara Modern Menganalisis Tumbuhan. Institut Teknologi Bandung, Bandung.

Huang, M. T., Ho. C. T. dan Lee C. Y. 1992. Phenolic Compounds In Food And 
Their Effects On Health II : Antioxidants and Cancer Prevention. American Chemical Society Symposium. 507. Washington D.C.

Hwang, T., Ndolo, V.U., Katunndu, M., Nyirenda, B., Kerr, R. B., Artifield. S. dan Beta, T. 2016. Provitamin A potential of Landrace Orange Maize Variety (Zea mays L.) Gown in Different Geographical Locations of Central Malawi. Journal Food Chemistry. 196 : 1315-1324.

Julkenen-Titto, R. $1985 . \quad$ Phenolic Constituents in Leaves of Northern Willows: Methods for the Analysis of Certain Phenolic. Journal Agriculture Food Chemistry. 33: 213-217.

Laeliocattleya, R. A., Prasiddha, I. J., Estiasih, T., Maligan, J. M. dan Muchlisyiyah, J. 2014. Potensi Senyawa Bioaktif Rambut Jagung (Zea mays L.) Hasil Fraksinasi Bertingkat Menggunakan Pelarut Organik untuk Tabir Surya Alami. Jurnal Teknologi Pertanian. 15(3). Universitas Brawijaya, Malang.

Landeng, P. J., Suryanto, E. dan Momuat, L. I. 2017. Komposisi Proksimat dan Potensi Antioksidan dari Biji Jagung Manado Kuning (Zea mays L.). Chemistry Progress. 10: 36-44.

Liu F., Xu Y., Jiang, H., Jiang, C., Du, Y., Gong, C., Wang, W., Zhu, S., Han, G., dan Cheng, B. 2016. Systematic Identification, Evolution an Expression Analysis of the Zea mays PHT1 Gene Family Reveals Several New Member Involved in Root Colonization by Arbuscular Mycorrhizal Fungi.
International Journal of Molecular Science. 17(930). Anhui Agricultural University, Hefei.

Lumempow, L. I., Suryanto, E. dan Paendong, J. 2012. Aktivitas Anti UVB Ekstrak Fenolik dari Tongkol Jagung (Zea mays L.). Jurnal MIPA Online. 1.

Mongkolsilp, S., Pongbupakit, I., Sae-lee, N. dan Sitthithaworn, W. 2004. Radical Scavenging Activity and Total Phenolic Content of Medical Plants Used in Primary Health Care. Jurnal of Pharmacy and Science. 9: 32-35.

Nely, F. 2007. Aktivitas Antioksidan Rempah Pasar dan Bubuk Rempah Pabrik dengan Metode Polifenol dan Uji AOM (Active Oxygen Method). IPB, Bogor.

Palungkun, R. dan Asiani, B. 2004. Sweet Corn-Baby Corn : Peluang Bisnis Pembudidayaan dan Penanganan Pasca Panen. Penebar Swadaya, Jakarta.

Parra, L. D. C., Saldivar, S. O. S. dan Liu, H. R. 2007. Effect of Processing on the Photochemical Profile and Antioxidant Activity of Corn For production of Masa, Tortillas, and Tortilla Chips. Journal of Algicultural and Food Chemistry. 55: 4177-4183.

Prasiddha, I. J., Lealiocattleya, R. A., Estiasih, T. dan Maligan, J. M. 2016. Potensi Senyawa Bioaktif Rambut Jagung untuk Tabir Surya Alami. Jurnal Pangan dan Agroindustri. 4(1). Universitas Brawijaya, Malang.

Pratimasari, D. 2009. Uji Aktivitas Penangkap Radikal Buah Carica papaya L. dengan 
Metode DPPH dan Penetapan Kadar Fenolik Serta Flavonoid Totalnya. Universitas Muhammadiyah, Surakarta.

Putri, H. A. 2011. Pengaruh Pemberian Beberapa Konsentrasi Pupuk Organik Cair Lengkap (POCL) Bio Sugih Terhadap Pertumbuhan dan Hasil Tanaman Jagung Manis (Zea mays saccharata Sturt). Universitas Andalas, Padang.

Shahidi, F. 1997. Natural Antioxidants: An Overview. In: Shahidi (eds). Natural Antioxidants: Chemistry, Health Effects and Application. AOCS Press, Champaign, Illinois.

Singleton.V.L., dan J.A. Rossi. 1965. Colorunetry of total phenolics with phosphomolybdicphosphotungstic acid reagents. American Journal Enology and Viticulture. 16: 145-158.

Suryanto, E. 2012. Fitokimia Antioksidan. PMN, Surabaya.

Wenur. S., Yamlean, P. V. Y. dan Sudewi, S. 2016. Formulasi dan Penentuan Nilai SPF dari Sediaan Losio Ekstrak Etanol Kulit Buah Pisang Goroho (Musa acuminafe L.). Pharmacon Jurnal Ilmiah Farmasi Unsrat. 5: 108-115. 